BIOMEDICAL AND BIOSOCIAL ANTHROPOLOGY
Official Journal of the International Academy
of Integrative Anthropology
journal homepage: http://bba-journal.com

\title{
Modern going near creation of in-hospital comfort for patients and medical personnel in psychiatric establishments of health protection
}

\section{Chorna V.V. ${ }^{1}$, Sergeta I.V. ${ }^{1}$, Makhnyuk V.M. ${ }^{2}$}

${ }^{1}$ National Pirogov Memorial Medical University, Vinnytsya, Ukraine

${ }^{2}$ SI "O.M. Marzieiev Institute for Public Health NAMSU", Kyiv, Ukraine

\section{ARTICLE INFO}

Received: 19 March 2019

Accepted: 30 April 2019

UDC: $614.212(477): 616.89(477)]$ :

$629.87(045)$

\section{CORRESPONDING AUTHOR}

e-mail: valentina.chorna65@gmail.com Chorna V.V.

\begin{abstract}
Today requires an important focus on providing psychological comfort both for health care professionals in preventing emotional burnout syndrome and inpatient comfort for patients in these settings. The purpose of the work is to carry out a comparative analysis of European experience on the principles of functional and aesthetic organization of interiors and decoration materials of premises of psychiatric health care institutions, to determine the characteristics of the influence of natural and artificial lighting on the psychophysiological state of the body of patients and medical professionals. The material of the study was Form № 18 of the Ministry of Health of Ukraine "Report on work on control of environmental factors affecting the state of health of the population" of the State Institution "Vinnytsia Regional Laboratory Center of the Ministry of Health of Ukraine" for the period 2016-2019. Content analysis of domestic and foreign scientific sources, as well as bibliosemantic, theoretical and analytical methods of research were used in the work. The statistical processing of the study results was performed in a licensed standardized package "Statistica 6.1 for Windows". As a result of studying the experience of European countries on the creation of inhospital comfort for patients and medical staff of psychiatric health care institutions, the following has been established: taking into account the sanitary and hygienic requirements in the design and arrangement of facilities for mentally ill persons should correspond to the therapeutic environment and promote the establishment of security regimen, improving treatment and prevention work, preventing hospital-acquired infections and therefore being one and the same priorities reform of mental health in Ukraine. According to the results of studying foreign experience on the basis of a systematic and ergo design approach to the re-profiling and reconstruction of existing psychoneurological hospitals in Ukraine, it is determined that its main purpose is to provide comfortable conditions for patients stay and create conditions for conducting psychosocial therapy and rehabilitation of persons with mental disorders. Therefore, the adaptation of hygiene requirements during the design and arrangement of the premises of psychiatric health care facilities should be aimed at ensuring the optimal individual and psychological status of patients and the appropriate parameters of the hospital environment and its sanitary and hygienic characteristics, which must correspond to the latest technology in providing high quality medical care using a biopsychosocial approach that will facilitate the transition to European standards.

Keywords: psychiatric establishments of health protection, condition of in-hospital comfort, world architectural and designer decisions.
\end{abstract}

\section{Introduction}

Most mental health facilities were built in the eighteenth and nineteenth centuries, based on the principle of "corridor" layout of the hospital premises, with little regard for the needs of psychological comfort. At the same time, it is important to place an important emphasis on providing psychological comfort for both health care workers in preventing emotional burnout syndrome and inpatient comfort for patients in these institutions (on average up to 53.5 days in Ukraine, 29.3 days i7n Poland, 
20.8 days in Lithuania) $[5,12,13,16,18,20,28,25,26]$.

According to $\mathrm{WHO}$, mental illness accounts for $13 \%$ of the global burden of all illnesses, with $3.4 \%$ of their total being depressive disorders. Moreover, WHO forecasts indicate that after 2030, depression will become a leading disease globally. This will be facilitated by the fact that in low- and middle-income countries, $76 \%$ to $85 \%$ of people with severe mental disorders do not receive treatment [21, 23, 27, 31].

European countries are investing heavily in the reconstruction and construction of new-type psychiatric health care facilities for full-fledged psychological comfort for patients with mental disorders, and this issue has not been fully resolved in Ukraine [3, 19, 22, 29, 32].

The purpose of the work is to carry out a comparative analysis of European experience on the principles of functional and aesthetic organization of interiors and decoration materials of premises of psychiatric health care institutions, to determine the characteristics of the influence of natural and artificial lighting on the psychophysiological state of the body of patients and medical professionals.

\section{Materials and methods}

The material of the study was Form № 18 of the Ministry of Health of Ukraine "Report on work on control of environmental factors affecting the state of health of the population" of the State Institution "Vinnytsia Regional Laboratory Center of the Ministry of Health of Ukraine" for the period 2016-2019. The paper used content analysis of domestic and foreign scientific sources, as well as bibliosemantic (to analyze the use of regulatory and legal regulation), theoretical (retrospective use of scientific research data based on scientific literature, electronic resources) and analytical methods of research. The statistical processing of the study results was performed in the licensed standardized package "Statistica 6.1 for Windows".

\section{Results}

Using the data of form № 18 of the Ministry of Health of Ukraine "Report on work on control of environmental factors affecting the state of health of the population" for the period 2016-2019, we studied the issues of the inpatient environment of health care establishments in Vinnytsia region. According to the results of the research, it is established that the State Institution "Vinnytsia Regional Laboratory Center of the Ministry of Health of Ukraine" constantly conducts inspections of health care establishments with the use of laboratory measurements of lighting, microclimate, noise, etc.

Artificial and natural lighting in the wards, at the post of the nurse, procedure rooms, doctors' offices, in the corridors shall correspond to the SBC B.2.5.-28: 2018 "Natural and artificial lighting". The natural illumination of the Vinnytsia hospital wards complies with the sanitary and hygienic requirements of NLF 1.0-1.5 because the wards are more southeast and south oriented. According to the data (Table 1), the highest indicator of job non-compliance in Vinnytsia oblast health care
Table 1. Indicators of artificial illumination in medical establishments of Vinnytsia region for 2016-2019.

\begin{tabular}{|c|c|c|c|c|}
\hline Year & $\begin{array}{c}\text { The number of } \\
\text { measurements of } \\
\text { artificial lighting }\end{array}$ & $\begin{array}{c}\% \text { not } \\
\text { matching }\end{array}$ & $\begin{array}{c}\text { Number of } \\
\text { jobs } \\
\text { surveyed }\end{array}$ & $\begin{array}{c}\% \text { not } \\
\text { matching }\end{array}$ \\
\hline 2019 & 4828 & 8.7 & 747 & 10.7 \\
\hline 2018 & 4016 & 4.6 & 819 & 3.8 \\
\hline 2017 & 3926 & 9.5 & 777 & 11.8 \\
\hline 2016 & 1008 & 3.5 & 202 & 5.0 \\
\hline
\end{tabular}

Table 2. Indicators of meteofactors in medical establishments of Vinnytsia region.

\begin{tabular}{|c|c|c|c|c|}
\hline Year & $\begin{array}{c}\text { The number of } \\
\text { measurements }\end{array}$ & $\begin{array}{c}\% \text { not } \\
\text { matching }\end{array}$ & $\begin{array}{c}\text { Number of jobs } \\
\text { surveyed }\end{array}$ & $\begin{array}{c}\% \text { not } \\
\text { matching }\end{array}$ \\
\hline 2019 & 6218 & 4.8 & 792 & 9.5 \\
\hline 2018 & 6517 & 4.1 & 837 & 9.0 \\
\hline 2017 & 6726 & 4.4 & 1059 & 6.7 \\
\hline 2016 & 1935 & 10.2 & 217 & 12.9 \\
\hline
\end{tabular}

establishments was $11.8 \%$ in 2017, and the lowest in 2018 was $3.8 \%$, which was in violation of the requirements of the SBC B.2.5.-28: 2018 "Natural and artificial lighting".

In hospital rooms (in wards, doctors' offices, dining rooms and other rooms) one of the most important sanitary and hygienic requirements is to create silence, ie the noise in these rooms should not exceed $30 \mathrm{~dB}$. According to the analysis of Form № 18, over these years, 1611 measurements were performed that met the requirements. In all medical establishments for 2016-2019 the parameters of the microclimate according to SSS 3.36.042-99 "Sanitary norms of the microclimate of industrial premises" were as follows (Table 2).

The highest proportion of non-compliant measurements was observed in $2016-10.2 \%$ and more stable over the last three years $-4.4 \%$.

\section{Discussion}

The influence on the health and hygiene and antiepidemic regimen of health care establishments is caused by changes in the microclimate and air environment parameters for which health care workers are responsible. Creation of sanitary and hygienic conditions in hospitals is an important factor in the prevention of hospital infections, optimization of the hospital environment, improvement of conditions in the medical work of medical staff, as well as the rapid recovery of patients $[4,33]$.

Mental health care in Ukraine accounts for $2.5 \%$ of the total health care budget, of which $89 \%$ is for mental health care. At the same time, financing for the reform of the mental health care system in the Republic of Poland is provided at the expense of the state budget and self-government funds, as well as at the expense of the European Union. About 20 million zlotys are allocated to this program annually. In the Czech Republic in 2019, 1.57 million korunas has been allocated for the construction of new psychiatric institutions and the reconstruction of existing buildings $[14,32]$. 
The draft action plan to implement the Concept of the State Targeted Program for the Mental Health of Ukraine for the Period up to 2030 provides many directions for overcoming numerous mental health problems, for example, to overcome stigma, reduce discrimination and violations of the rights of the mentally ill, exercise preventive measures for children, the elderly and war veterans with mental health problems. However, the number of beds in specialized psychiatric hospitals is reduced by $25 \%$ and the number of psychiatric and psychosomatic units in general hospitals is increased. Instead, there are no measures at all on architectural and planning decisions of construction, reconstruction of psychiatric hospitals, specialized medical centers [3, 11, 23].

Instead, addressing hygiene requirements when designing and equipping healthcare facilities should be one of the priority areas for mental health reform. In order to do this, it is necessary to update the statutory requirements for mental health institutions in order to comply with current European standards. Conditions in psychiatric institutions should be fully consistent with the therapeutic environment and contribute to the creation of the best conditions for the provision of health care, improving treatment and prevention work, preventing the emergence of nosocomial infections. In this context, it should be noted that the therapeutic environment should be defined as a patient care environment that helps to make patients more susceptible to medical treatment. European countries staffing psychiatric patients assure that a built environment where patients receive quality services should be reminiscent of the "typical residential" atmosphere in which patients can feel relaxed and comfortable. European country architects work closely with hospital staff, patient groups, interior designers and psychiatric hospital consultants [10, 12].

In 1997, the USA approved a list of interior elements for mental health institutions that have a positive therapeutic effect and improve the quality of life of patients in the treatment of the mentally ill by using modern design combinations: light and color, textured and natural materials, sounds (nice tunes) and other elements to meet the needs of patients and staff. The design considers key components of the final design, such as the average length of stay of patients, features of diagnoses, severity of disease, age and related medical conditions, whether voluntary or court-ordered. For the designer of psychiatric hospitals, the main task should be considered to be patient and medical safety, improvement of the spatial orientation of the hospital premises, ease of use of its equipment, suicide prevention, etc. [1, 9].

According to the results of both objective studies and subjective survey of patients and health care workers in Russia, Italy, the Netherlands on the impact of natural and artificial illumination on the psychophysiological status of patients and doctors, four mental health institutions revealed a decrease in the number of stressful situations, the presence of their pronounced positive impact on the course of the treatment process, reducing the recovery time, reducing the duration of medical treatment then what. At the same time, in the absence of daylight in the medical premises of health care institutions, the presence of the phenomena of pronounced visual tension, increased errors in work, expression of the spread of some signs of the syndrome of emotional burnout of health workers were observed. Objective research was conducted in 70 different rooms, both in the bedrooms and in the offices of doctors and nurses, both in the nineteenth century and modern buildings. Studies have shown that the power of artificial electric lighting measured above the surfaces, observation beds and desks of doctors in $90 \%$ of cases did not meet the existing regulatory values, which indicates the need for more accurate design of the type of lamps in psychiatric health institutions [9].

When designing psychiatric hospitals, European countries' architects pay attention to the following safety principles: the use of natural, textured, colored materials that provide a more cozy, almost home-like atmosphere; providing sufficient natural light and the location of artificial light sources so that the patient's access to the light bulbs, and therefore to their glass and electrical contacts, is restricted, the luminaires must have large lenses securely in place; upholstered furniture should be made of wood and firmly in place to avoid injury or death, cabinets with doors for personal belongings should only be replaced by shelves that are securely secured; bathrooms should be designed with security in mind so that they do not lead to catastrophic consequences.

The windows do not have curtains or vertical blinds of any kind to minimize the risk of suicide. Psychiatric institutions use special glass materials and films that are resistant to hurricanes and firearms, which significantly increase the degree of their resistance to destruction.

A towel dryer is one of the most crucial examples of controversial issues that architects need to address immediately. These devices are always securely secured, and thus pose a great risk of hanging (suicide) [17, 15]. The number of suicides committed in psychiatric wards is $8.6 \%$ [1]. And after analysis of suicides in psychiatric institutions, it was found that 50 percent of hangings were from heights below the victim's waist.

When designing mental health facilities, architects pay attention to all aspects of room design, including the following: for several years, the institutional type of shower enclosures that work reasonably well in this environment has been selected, with various water control valves to control water temperature and duration, there should be no flow, the handwashing capacity should be recessed and have no handles, the shower cubicles should be designed so that no shower curtain is needed. The use of shower curtains in psychiatric facilities is also not recommended in terms of patient safety $[8,24,30]$.

In the United States, there were 559,000 people in closed state mental hospitals in 1955, with a total population of 165 million, and already in 1998, with an increase in the country's population to 275 million, 57,000 patients were being treated 
in psychiatric hospitals. For example, in California, fewer than three beds were occupied per 100,000 people. The results of deinstitutionalization in the USA showed the main ways of solving all the major problems of modern psychiatry, namely: eradicating the phenomenon of stigmatization of the mentally ill by society and by the sick themselves; providing housing for homeless mentally ill people, who in the United States at that time accounted for up to $75 \%$ of their total population, and who had been diagnosed with severe psychiatric illness and other categories of mentally ill patients for treatment through a so-called environmental model. In particular, up to $78 \%$ of patients received treatment, counseling and rehabilitation in dormitories of psychosocial care, $11 \%$ of patients lived independently in dormitories, 7 $\%$ of patients stayed in dormitories without special staff, $4 \%$ of patients lived with family [7].

According to the current scientific literature $[2,6]$, there are currently five levels of patient safety concerns identified in the design of facilities for the mentally ill in the United States, which are identified in the patient risk assessment matrix and have unique design constraints:

Level I: direct supervision by permanently present medical staff. That is, only patient care areas where patients are under constant supervision should be provided;

Level II: high observance. These are areas (corridors, consulting rooms, active rooms) where patients are fully monitored and remain alone for very short periods of time. Corridors often have high ceilings and standard fixtures. Medical staff may not always be present in such areas;

Level III: periodic observation. These areas include: television and observation rooms, halls and day rooms where patients spend time with minimal supervision. The decisions regarding the need for the design of such premises are discussed with the staff of the institution;

Level IV: minimal observation. Areas where patients spend a large amount of time alone with minimal supervision of healthcare providers or in the absence of such supervision, such as patient rooms (semi-private and private), showers and patient toilets;

Level V: examination and waiting rooms in which staff interact with newly admitted patients who may be in a highly excited state. There should be a minimum of furniture in these rooms and everything should be securely in place. Keep computers, phones, cords, and cables away from patients. Signaling in such premises is mandatory during design [8].

According to the analytical report of the Ukrainian Helsinki Human Rights Union, during the survey of three regional psychiatric hospitals in Mykolaiv, Poltava and Kherson regions, many shortcomings were identified: patients' rights to leisure and recreation are violated, and funding for treatment, nutrition, rehabilitation and educational services is insufficient. The area of rooms per patient and the

\section{References}

[1] Betz, M. E., \& Boudreaux, E. D. (2016). Managing suicidal patients in the emergency department. Annals of emergency occupancy of patients in the same ward with 4 to 14 patients, the absence of bedside tables or cabinets for each patient, outdated bedding, etc. are of concern. According to patients, toilet and shower rooms are uncomfortably far from the wards. Bathrooms are combined with personal hygiene rooms, but they are closed and you should always consult a health care provider. None of the hospitals have occupational treatment rooms, although the posts of instructors for educational services, religious services, concerts, creative evenings, birthdays and more exists [16, 22, 23].

On the other hand, it should be noted that in Ukraine, according to the Ministry of Health, the process of deinstitutionalization is extremely significant - reducing the number of beds from 39251 in 2012 to 31857 in 2014 - 74.3 beds per 100 thousand population. But the major problems that the US and many European countries have overcome have not been resolved in Ukraine. First of all, there are no conditions for the implementation of a multidisciplinary approach for those who are outside hospitals, out of the state's attention, there are no conditions for self-living and receiving services at community level by persons with intellectual and psychosocial disability, etc. [10, 11, 12].

\section{Conclusions}

1. As a result of studying the experience of the European countries on the creation of in-hospital comfort for patients and medical staff of psychiatric health care institutions, the following has been established: taking into account the sanitary and hygienic requirements in the design and arrangement of facilities for mentally ill persons should be appropriate to the therapeutic environment and promote the environment health-care regimen, improving treatment and prevention work, preventing hospital-acquired infections, and therefore being one of the priority areas of mental health reform in Ukraine.

2. According to the results of studying foreign experience on the basis of a systematic and ergo design approach to the re-profiling and reconstruction of existing psychoneurological hospitals in Ukraine, it was determined that its main purpose is to provide comfortable conditions for patients stay and create conditions for conducting psychosocial therapy and rehabilitation of persons with mental disorders.

3. Adaptation of hygienic requirements during the design and arrangement of premises of psychiatric health care facilities should be aimed at ensuring the optimal individual and psychological status of patients and the appropriate parameters of the hospital environment and its sanitary and hygienic characteristics, which must correspond to the latest technologies in providing the latest technologies for providing qualified medical care using a biopsychosocial approach that will facilitate the transition to European standards.

medicine, 67(2), 276-282. http://dx.doi.org/10.1016/ j.annemergmed.2015.09.001. 
[2] Carr, R. F. (2011). Psychiatric facility. Design Guidance. Retrieved from http://www. wbdg. org/design/psychiatric.php

[3] CMU (2017). The concept of mental health development in Ukraine until 2030 (PROJECT). CMU Ordinance № 1018.

[4] Derby, M. M., Hamehkasi, M., Eckels, S., Hwang, G. M., Jones, B., Maghirang, R., \& Shulan, D. (2017). Update of the scientific evidence for specifying lower limit relative humidity levels for comfort, health, and indoor environmental quality in occupied spaces (RP-1630). Science and Technology for the Built Environment, 23(1), 30-45. http://dx.doi.org/10.1080/ 23744731.2016.1206430

[5] Detsyk, O. Z., \& Zolotarova, Zh. M. (2015). Organizational technology for combating and combating the professional burnout of palliative care workers. Rehabilitation and palliative medicine, (2), 93-97. dol: 10.15574/URPM.2015.01.14

[6] Facility Guidelines Institute (2014). Guidelines for Design and Construction of Hospitals and Outpatient Facilities. American Society for Healthcare Engineering Sustainable. https:// www.fgiguidelines.org/wp-content/uploads /2015/08/ 2014_FGI_SustainableDesign_HOP.pdf

[7] Griffiths, K. M., Christensen, H., Jorm, A. F., Evans, K., \& Groves, C. (2004). Effect of web-based depression literacy and cognitivebehavioural therapy interventions on stigmatising attitudes to depression: Randomised controlled trial. The British Journal of Psychiatry, 185(4), 342-349. doi: 10.1192/bjp.185.4.342

[8] Hunt, J. M., \& Sine, D. M. (2009). Common mistakes in designing psychiatric hospitals. AlA Academy Journal. Retrieved from http://www.aia.org/groups/aia/documents/pdf/aiab090822.pdf

[9] Hunt, J. M., \& Sine, D. M. (2014). Design guide for the built environment of behavioral health facilities. National Association of Psychiatric Health Systems. https://www.fgiguidelines.org/ wp-content/uploads/2017/03/DesignGuideBH_7.2_1703.pdf

[10] Hurovych, I. Ya., Storozhakova, Ya. A., \& Fursov, B. B. (2012). International experience in the reform of psychiatric care and the further development of psychiatric services in Russia. Social and Clinical Psychiatry, 22(1), 5-18.

[11] Imerelli, R. E., Kazachynska, K. P., Moisa, B. S., \& Shum, S. S. (2016). Rights of persons with mental health problems. Human rights in psychiatric hospitals. Analytical Report of the Ukrainian Helsinki Human Rights Union. Ukrainian Helsinki Human Rights Union. K.: KYT.

[12] International medical corps (2017). Mental health in transition: evaluation results and recommendations for integrating mental health care into primary care and community platforms in Ukraine. World bank group.

[13] Kastnerova, M., Babinets, L. S., Borovyk, I. O., \& Babinets, A. I. (2017). Prevalence of burn out syndrome among nurses in hospitals in the South Bohemia region. Achievements of clinical and experimental medicine, (3), 82-87. doi: 10.11603/18112471.2017/v1.i3.8053

[14] Kazhyn, V. A. (2014). Actual problems of psychiatry in European countries and the structure of psychiatric care on the example of Germany. Perm Medical Journal, 31(2), 123-130.

[15] Kovalov, Yu. M., \& Kfia, D. V. (2013). Color design of interiors of psychiatric hospitals. Design theory and practice, (3), 58-69. http://nbuv.gov.ua/UJRN/

[16] Lekhan, V. M., \& Kriachkova, L. V. (2019). A system of measures to improve the health of the Ukrainian population based on an analysis of the global burden of disease and its risk factors. Medical perspectives, 24(3), 113-122. https://doi.org/10.26641/ 2307-0404.2019.3/181893

[17] Lo Verso, V. R., Caffaro, F., \& Aghemo, C. (2016). Luminous environment in healthcare buildings for user satisfaction and comfort: An objective and subjective field study. Indoor and Built Environment, 25(5), 809-825. doi: 10.1177/ $1420326 \times 15588337$

[18] Maruta, N. O., \& Chaban, O. S. (2019). Features of emotional burnout in neurological and mental health care professionals. International Neurological Journal, 7(109), 22-29. doi: 10.22141/2224-0713.7.109.2019.183009

[19] Masiakyn, A. V., \& Kostiuk, G. P. (2018). Possible ways to increase the effectiveness of psychiatric care. Neurology, neuropsychiatry, psychosomatics, 10(2), 109-113. doi: 10.14412/2074-2711-2018-2-109-113

[20] Mazepa, Y. S., Pishchikov, V. A., \& Sydorenko, O. O. (2016). Diagnosis of occupational burnout syndrome for doctors at $a$ multidisciplinary healthcare facility. Achievements of clinical and experimental medicine, (4), 67-69. doi: 10.11603/18112471.2016.v0.i4.7081

[21] Nguyen, T., Tran, T., Tran, H., Tran, T., \& Fisher, J. (2019) Challenges in Integrating Mental Health into Primary Care in Vietnam. In: Okpaku S. (eds) Innovations in Global Mental Health. Springer, Cham. https://doi.org/10.1007/978-3-319-70134-9_741/

[22] Pinchuk, I. Ya. (2016). Qualitatively new functional and organizational system of psychiatric care within the framework of reforming the health care system of Ukraine: organizational and legal aspect. Economics and Health Law, (2), 81-88.

[23] Pohoriliak, R. Yu., \& Hulchii, O. P. (2018). Dependence of changes in public health indicators and indicators of quality assessment and availability of care on changes in resources. Ukraine. Nation's health, (3), 62-65. http://nbuv.gov.ua/UJRN/ Uzn_2018_3_12

[24] Puras, D., \& Gooding, P. (2019). Mental health and human rights in the 21st century. World Psychiatry, 18(1), 42-43. doi: 10.1002/ wps. 20599

[25] Reshetnykov, M. M. (2015). Mental health of the population current trends and old problems. National Psychological Journal, 1(17), 9-15. doi: 10.11621/npj.2015.0102

[26] Shafranskyi, V. V., \& Dudnyk, S. V. (2016). Mental health of the Ukrainian population: status, problems and solutions. Ukraine. Nation's health, (3), 12-18. http://nbuv.gov.ua/UJRN/ Uzn_2016_3_4

[27] Timashova, V. M., \& Timashov, V. A. (2017). Mental health as a component of the conceptual sphere of health and a promising direction for the development of the mental health service in Ukraine. Likars'ka sprava, (7), 250-255. https://liksprava.com/ index.php/journal/article/view/351

[28] Vezhnovets, T. A. (2017). Research on job satisfaction and burnout syndrome in healthcare professionals. ScienceRise. Medical science, 2(10), 36-40. http://nbuv.gov.ua/UJRN/ texcsrm_2017_2_9

[29] Votruba, N., Ziemann, A., Grant, J., \& Thornicroft, G. (2018). A systematic review of frameworks for the interrelationships of mental health evidence and policy in low-and middle-income countries. Health research policy and systems, 16(1), 85. doi: 10/1186/s12961-018-0357-2

[30] WHO (2009). Improving health systems and services for mental health. https://www.who.int/ru/news-room/fact-sheets/detail/ mental-health-strengthening-our-response

[31] WHO (2011). The global burden of mental disorders and the need for a comprehensive, coordinated response from the health and social sectors at the country level. 130 session, paragraph 6.2.

[32] Zakal, Yu. (2011). Mental health care in the Republic of Poland. Bulletin of the Association of Psychiatrists of Ukraine, (2), 18- 
24. http://www.mif-ua.com/archive/article/27208

[33] Zinkler, M., \& von Sebastian, P. (2019). End Coercion in Mental Health Services-Toward a System Based on Sypport Only.
Laws, MDPI, Open Access Journa, 8(3), 1-10. https://doi.org/ 10.3390/laws8030019

\section{СУЧАСНІ ПІДХОДИ ДО СТВОРЕННЯ ВНУТРІШНЬОЛІКАРНЯНОГО КОМФОРТУ ДЛЯ ХВОРИХ ТА МЕДИЧНОГО ПЕРСОНАЛУ У ПСИХІАТРИЧНИХ ЗАКЛАДАХ ОХОРОНИ ЗДОРОВ'Я \\ Чорна В.В., Сергета І.В., Махнюк В.М.}

Сьогодення вимагає робити важливий акцент на забезпеченні психологічного комфорту як для працівників медичних закладів щодо запобігання синдрому емоційного вигорання, так і внутрішньолікарняного комфорту для пацієнтів, які перебувають в цих закладах. Мета роботи - проведення порівняльного аналізу європейського досвіду щодо принципів фуункціональної $i$ естетичної організації інтер'єрів та оздоблювальних матеріалів приміщень психіатричних закладів охорони здоров'я, визначення особливостей впливу природного та итучного освітлення на психофрізіологічний стан організму хворих і медичних працівників. Матеріалом дослідження стали фформи № 18 МОз України "Звіт про роботу з контролю за фракторами навколишнього середовища, що впливають на стан здоров'я населення" ДУ "Вінницький обласний лабораторний центр МОЗ України" за період 2016-2019. У роботі використовувалися контент-аналіз вітчизняних та зарубіжних наукових джерел, а також бібліосемантичні, теоретичні та аналітичні методи досліджень. Статистична обробка результатів дослідження виконана в ліцензійному стандартизованому пакеті "Statistica 6.1 for Windows". В результаті вивчення досвіду Європейських країн щодо створення внутрішньолікарняного комфорту для хворих та медичного персоналу психіатричних закладів охорони здоров'я встановлено наступне: врахування санітарно-гігієнічних вимог при проектуванні і облаштуванні закладів для психічнохворих осіб повинне відповідати терапевтичному середовищу та сприяти створенню найкращі умови для організації лікувально-охоронного режиму, покращення лікувально-профрілактичної роботи, запобігання внутрішньо-лікарняних інфекцій i, отже, бути одне із пріоритетних напрямків реформи охорони психічного здоров'я в Україні. За результатами вивчення закордонного досвіду на основі системного та ергодизайнерського підходу при перепрофілюванні і реконструкції існуючих психоневрологічних лікарень в Україні, визначено, що його основною метою $є$ забезпечення комфортних умов перебування пацієнтів та створення умов для проведення психосоціальної терапії і реабілітації осіб з психічними розладами. Тому адаптація гігієнічних вимог під час проектування та облаштування приміщень психіатричних закладів охорони здоров'я має бути спрямована на забезпечення оптимального індивідуально-психологічного стану пацієнтів і відповідних параметрів внутрішньолікарняного середовища та його санітарно-гігієнічних характеристик, які повинні відповідати новітнім технологіям щодо надання на сучасному рівні кваліфрікованої медичної допомоги із використанням біопсихосоціального підходу, що сприятиме переходу на європейські стандарти.

Ключові слова: психіатричні заклади охорони здоров'я, умови внутрішньолікарняного комфорту, світові архітектурні $i$ дизайнерські рішення.

\section{СОВРЕМЕННЫЕ ПОДХОДЫ К СОЗДАНИЮ ВНУТРИБОЛЬНИЧНОГО КОМФОРТАДЛЯ БОЛЬНЫХ И МЕДИЦИНСКОГО ПЕРСОНАЛАВ ПСИХИАТРИЧЕСКИХ ЗАВЕДЕНИЯХ ЗДРАВООХРАНЕНИЯ}

\section{Черная В.В., Сергета И.В., Махнюк В.М.}

Настоящее требует вносить важный акцент на обеспечении психологического комфорта как для работников медицинских учреждений по предотвращению синдрома эмоционального выгорания, так и внутрибольничного комфорта для пациентов, находящихся в этих учреждениях. Цель работы - проведение сравнительного анализа европейского опыта принципов фоннкциональной и эстетической организации интерьеров и отделочных материалов помещений психиатрических учреждений здравоохранения, определение особенностей влияния естественного и искусственного освещения на психофизиологическое состояние организма больных и медицинских работников. Материалом исследования стали фоормы № 18 МОз Украины "Отчет о работе по контролю за фракторами окружающей среды, влияющие на состояние здоровья населения" ГУ "Винницкий областной лабораторный центр МЗ Украины" за период 2016-2019. В работе использовались контент-анализ отечественных и зарубежных научных источников, а также библиосемантический, теоретический и аналитический методы исследований. Статистическая обработка результатов исследования выполнена в лицензионном стандартизированном пакете "Statistica 6.1 for Windows". В результате изучения опыта Европейских стран относительно создания внутрибольничного комфорта для больных и медицинского персонала психиатрических заведений здравоохранения установлено следующее: учет санитарно-гигиенических требований при проектировании и обустройстве заведений для душевнобольных лиц должен отвечать терапевтической среде и способствовать созданию наилучшие условия для организации лечебно-охранительного режима, улучшения лечебно-профилактической работы, предотвращения внутренне больничных инфрекций и, следовательно, быть одно из приоритетных направлений реформы здравоохранения психического в Украине. За результатами изучения заграничного опыта на основе системного и эргодизайнерского подходов при перепрофилировании и реконструкции существующих психоневрологических больниц в Украине, определенно, что его основной целью является обеспечение комфортных условий пребывания пациентов и создания условий для проведения психосоциальной терапии и реабилитации лиц с психическими расстройствами. Поэтому адаптация гигиенических требований во время проектирования и обустройства помещений психиатрических заведений здравоохранения должна быть направлена на обеспечение оптимального индивидуально психологического состояния пациентов и соответствующие параметры внутрибольничной среды и его санитарно-гигиенических характеристик, которые должны отвечать новейшим технологиям относительно предоставления на современном уровне квалифицированной медицинской помощи $c$ использованием биопсихосоциального подхода, который будет способствовать переходу на европейские стандарты.

Ключевые слова: психиатрические учреждения здравоохранения, условия внутрибольничного комфорта, мировые архитектурные и дизайнерские решения. 